\title{
Landscapes of the African American Diaspora in Denmark
} - An Imaginary Exhibition

\begin{abstract}
This imaginary exhibition is based on the archive of items collected to write the book manuscript for Searching for Utopia: African Americans in $20^{\text {th }}$ Century Denmark. Professor Ethelene Whitmire used the method of curatorial dreaming to design this exhibition and was influenced by African American expatriate Walter Williams's landscape paintings that reflect the themes in the book.
\end{abstract}

Keywords: African American, diaspora, Denmark, archives, exhibition

\section{Landscapes of the African American Diaspora in Denmark: An Imaginary Exhibition}

I am writing a book about African Americans who lived, studied, visited, and performed in $20^{\text {th }}$ century Denmark. In the beginning of the $20^{\text {th }}$ century educators, civil rights activists, scholars, social workers and union organizers went to Denmark to study the adult folk schools and cooperative movements for farmers. They hoped to create similar programs to help African American sharecroppers, tenant farmers and members of the Great Migration. Although their primary reason for going to Denmark was to uplift the race, many also had a secondary motivea sense of adventure and a respite from racism and segregation in the United States. In the second half of the century, African Americans went to Denmark for more individual reasons and began permanently living there. Artists and performers like jazz saxophonist Dexter Gordon and singer Ella Fitzgerald found financial and creative support for their work in Denmark as well as romance. Many married Danes and started families-often second families for the frequently middle-aged jazz musicians. The artists, writers and musicians also felt that the lack of state-sanctioned, racial segregation created an atmosphere in Denmark that increased their productivity.

My book project includes famous and unknown African American scholars, musicians, writers, diplomats, and activists, among many others. Many viewed Denmark as a racial utopia. Several men including baseball player Curt Flood said they felt like a "human being" while in Denmark (Vecsey, 1970). Others thrived in their creative professions, finding renewed passion in Denmark where they could live more freely. Jazz musician Sahib Shihab, 


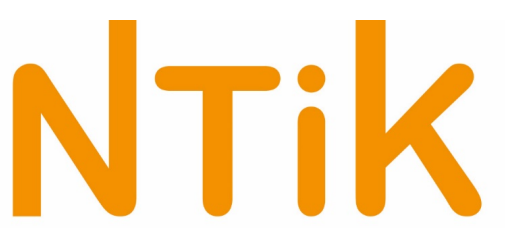

Nordisk Tidsskrift for Informationsvidenskab og Kulturformidling

describing his experiences in the United States, said, "I don't have time for this racial bit. It depletes my energies" (Lind, 1963, p. 38).

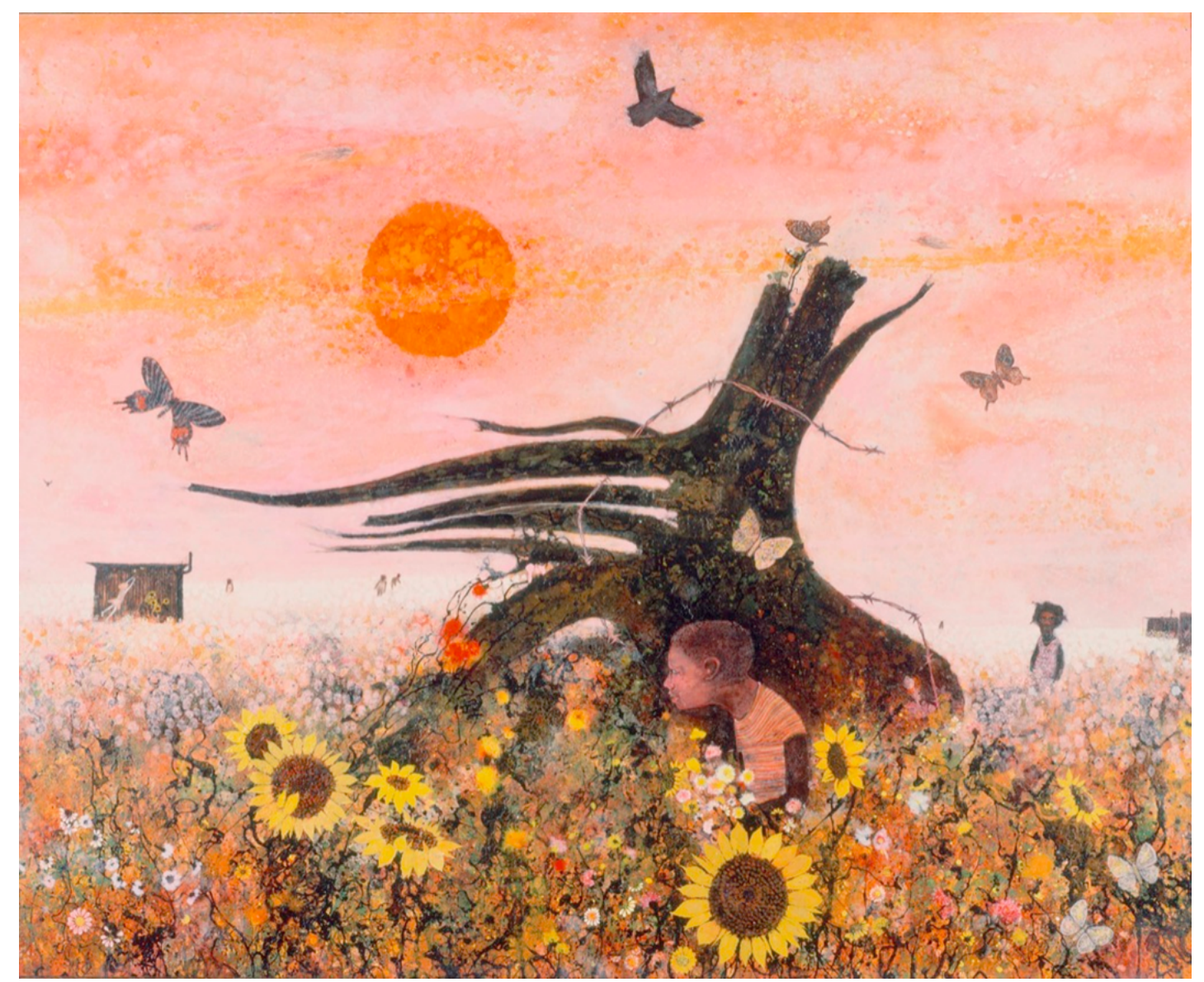

Figure 1. Walter Williams Roots, Southern Landscape (1978). Oil, sand, enamel, collage. $121.3 \times 149.3 \mathrm{~cm}$ (47 $3 / 4 \times 583 / 4$ in.) Collection of Camille O. and William H. Cosby Jr. Courtesy of Walter Williams' Estate.

\section{Data Sources for Searching for Utopia: African Americans in $20^{\text {th }}$ Century Denmark}

While writing and researching my book I collected hundreds of primary sources including: personal letters, Danish government records (for example, the Udlændingesager records, nicknamed the Foreigner Files, in the Danish National Archives), Danish and African American newspaper articles and columns, scrapbooks, photographs, images of paintings and prints, a film, documentaries, novels, a short story, music, interviews and many other documents. During this time, I was thinking about how to represent the story I was writing in a different medium as a multimedia presentation. I wanted to reach new audiences who would not necessarily read Searching for Utopia. I came across a book that proposed an alternative method of presenting scholarly research as an exhibition.

\section{Curatorial Dreaming and Imaginary Exhibits}

The book, Curatorial Dreams: Critics Imagine Exhibitions, described the method of curatorial dreaming. It is an alternative means of knowledge production-a technique to help academics translate their scholarly work into an exhibition that reaches a broader audience. The creators, scholars Shelley Ruth Butler and Erica Lehrer, 
encourage academics to use creative titles, venues, and to select "evocative descriptions of key exhibitionary moments" (Butler and Lehrer, 2016, p. 4). They see exhibitions as arguments that curators are trying to make to show visitors a way of seeing. They urge scholars to "set aside linear models of knowledge dissemination" and consider other ways of exhibiting their work (Butler and Lehrer, 2016, p. 10). Butler described the process of conducting a curatorial dreaming workshop to create an exhibition or intervention (Butler, 2018).

One example of creating a real exhibition from a curatorial dream is "Visual Footnotes: Counter Memories and Art from a Fractured Past in Post-Conflict Peru" exhibition. The exhibition was designed as "an immersive strategy to present and encourage reflections about research journeys." One visitor said, "I feel like I'm standing inside the book!" (Angarita, 2016). I want visitors of my imaginary exhibition to feel like they are standing inside my archive.

One inspiration for my curatorial dream is the art of Walter Williams (1920-1998), an African American expatriate in Denmark. Artist and art historian David C. Driskell described Roots, Southern Landscapes (see Figure 1), by Williams as:

an oil painting with bits of paper collaged throughout its roughly painted surface, is one of many variations on the theme of Southern Landscape. It was a subject Williams began creating in the early 1960s. Repetitive symbols that appear often in Williams's work-blackbirds, butterflies, sunflowers, children collecting bouquets of flowers, and a bright red sun-tell us that a warm and colorful romance between the viewer and the southern landscape is about to take place. But central to all these symbols is an upturned tree trunk with its bare black roots exposed to the heat of the southern sun. The trunk of the tree is partly entwined by barbed wire.

As handsome as this romance of nature may seem, as shown in the curious gaze of black children playing innocently in the surrounding countryside, Roots, Southern Landscape is a tour de force in cultural subversion. It is an accomplished form of social commentary art under the guise of a well-planned painterly statement. The upturned tree trunk and its barbed wire represent African Americans in the flowering fields of wealth in America, uprooted from their home in Africa and partly hemmed in by the inhumane rules of slavery, then segregation. The sunflower echoes the warmth of the sun and represents faith and hope for the future. The birds and butterflies symbolize the flight to full freedom and first-class citizenship desired by all oppressed people. The shacks in the background reaffirm the poverty of the rural south, a visual reoccurrence often noted in William's paintings (Driskell, 2001, p. 138).

In the fall 2014, the Smithsonian National Museum of African Art in the United States had an exhibition, Conversations: African and African American Artworks in Dialogue. The exhibition was organized by Williams' friend David C. Driskell along with independent scholar Adrienne L. Childs, and curator Bryna Freyer. The exhibit's chief curator and the museum's deputy director Christine Mullen Kreamer, said of the 50 pieces on loan from the Camille O. and William H. Cosby Jr. Collection, that this piece by Walter Williams, Roots, Southern Landscape, was "one of our favorite pieces.' It's so powerful this notion of African American History" (Andrews-Dryer, 2014). This piece was included under the theme, Nature as Metaphor, and the text that accompanied this work describes it as:

A fairly overt political approach to the landscape is found in Roots, Southern Landscape, by the expatriate African American artist Walter Williams. In this dreamy, almost fantastic landscape, children play and butterflies drift around a large, dark, upturned tree root that is entangled in barbed wire. This ominous dead tree seems like an incongruous element in a field full of sunflowers and other colorful foliage. However, upon closer examination, we find that the field of flowers turns into a cotton field. Small figures, perhaps children, pick cotton among several shacks. Williams has fashioned a landscape in which the roots of American slavery and tenant farming are sites of memory wherein the severed roots of the first Africans in America are recalled. However, his depictions of young children, flowers, and butterflies, along with his use of warm, energetic yellow, orange, and pink hues, evoke the promise of renewal (Smithsonian National Museum of African Art, 2014). 
This promise of renewal, a hope for a brighter day, echoed the themes of the African Americans in my book manuscript, Searching for Utopia: African Americans in $20^{\text {th }}$ Century Denmark. Artist Walter Henry Williams, Jr. was born on August 11, 1920 in Brooklyn. His mother Dorothy supported his interests in the arts but she died when he was five years old shortly after separating from his father. His father and stepmother raised Walter and his sister Dorothy and he put aside his dreams of being an artist. After high school, Williams served in WWII, married, and had two sons while he worked various blue-collar jobs to support the family. In 1948, shortly after the birth of his second son, Williams decided to pursue his passion for art and sacrificed his family in the process. He became part of a group of artists and musicians in the Greenwich Village including poet Alan Polite and his roommate, noted jazz musician Charlie "Bird" Parker. He shared studio space with artists Sam Middleton, Harvey Cropper, and Clifford Jackson-all would eventually live abroad too. They encouraged him to use his GI Bill to attend the Brooklyn Museum School of Art from 1951-1955 where he was taught by Ben Shahn and Reuben Tam. But, it was his instructor Gregorio Prestopino who had the greatest impact on his early art by influencing his choice of subjects, style, and the colors he used to capture children in urban settings.

In 1953, he attended the summer school of Skowhegan School of Painting and Sculpture where David Driskell, the only other African American student, was his roommate. Their friendship would span nearly half a century. Williams won first place for painting at Skowhegan. In 1955, he received the John Hay Whitney Foundation fellowship and used the funds to travel to Denmark. His trip "had a profound effect on him and changed the direction of his art." (Hanks, 2007, p. 24). Biographer Eric Hanks said, "Many black artists escaped to France but Williams chose Denmark because his maternal grandfather, who was from the Danish West Indies, always spoke so highly of the country and he was determined to see it for himself." (Hanks, 2007, pp. 24-25). During his time in Denmark, Williams frequently traveled to the Danish island of Bornholm. Williams' widow Marlena said that as a life-long city dweller he was "awestruck" noting,

it was the first time he really saw landscapes. His exposure to untouched nature was life-changing. He freed his subjects from an urban environment and placed them in the countryside. Children became principal themes. Birds, butterflies, sunflowers, watermelons and the sun became key imagery-symbolic of rebirth and resurrection, flight and freedom. He had discovered what he wanted to say in his work (Hanks, 2007, p. 25).

Williams returned briefly to the United States and then spent several years living and painting in Mexico before returning to the United States. He won $\$ 1,000$ from the Silvermine Guild Award for Oil Painting and used the funds to return to Denmark in 1964. He married Marlena Jacobsen later that year and they would eventually have a son, Darius, in 1973. Williams became a Danish citizen in 1979. During his years in Denmark Williams continued to paint, print, and sculpt and participated in shows in Denmark, the United States and around the world. He also taught in his studio in Frederiksberg. Williams died in 1998 at the age of seventy-seven years old and is buried in the grave of the unknowns in Bispebjerg Cemetery.

\section{The Exhibition}

The Venue

Ideally the exhibition would be in a field recreating the landscapes in Bornholm that inspired Walter Williams's Roots, Southern Landscapes and Southern Landscape paintings (see Figures 1 and 2). But, realistically it could be in a traditional museum or gallery space that has at least two rooms. For my imaginary exhibit, I want visitors to feel as if they are walking through Walter Williams's landscapes. The first room would recreate the settings of Roots, Southern Landscape and Southern Landscapes leading to the rest of the exhibit. Visitors would enter through the back of the paintings and make their way towards the front and the rest of the exhibit. The visitors would enter through the door of a shanty. The room would be quiet and quite dark, filled with cotton fields. As they exit the shack they hear blackbirds and start to see walls awash with vivid shades of orange, pink, and yellow and they see images of butterflies and sunflowers or preferably real sunflowers. The sounds of jazz music from expatriates Thad Jones, Ed Thigpen, Kenny Drew, Oscar Pettiford, Richard Boone, Ray Pitts, Ernie Wilkins, and Duke Jordan, among others begins to fill the space. In the middle of the exhibit there would be an upturned tree trunk striking a discordant note. 


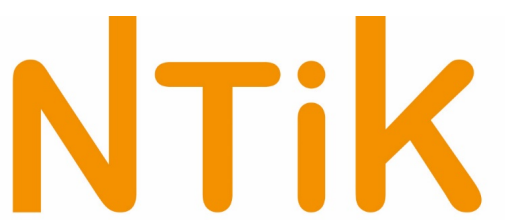

Nordisk Tidsskrift for Informationsvidenskab og Kulturformidling

Once the visitors walk through the sunflower fields, they can take a variety of paths. Although I am writing my book in a chronological, linear format, the visitors do not have to follow a straight path. Narrative Spaces: On the Art of Exhibiting suggests several ways of creating paths for visitors to experience exhibitions-what the authors call "The Walk." Two walks that would work with this exhibition are (1) "a labyrinthine environment conducive to encounters" where visitors do not have to follow a fixed route in order to understand the experiences of African Americans in Denmark, and (2) "a walk through different environments with different narrative perspectives," so that a visitor might form a positive impression of African American experiences in Denmark in one section and then see or hear something that makes them question their previously held assumptions (Kossmann, Mulder, \& den Oudsten, 2012).

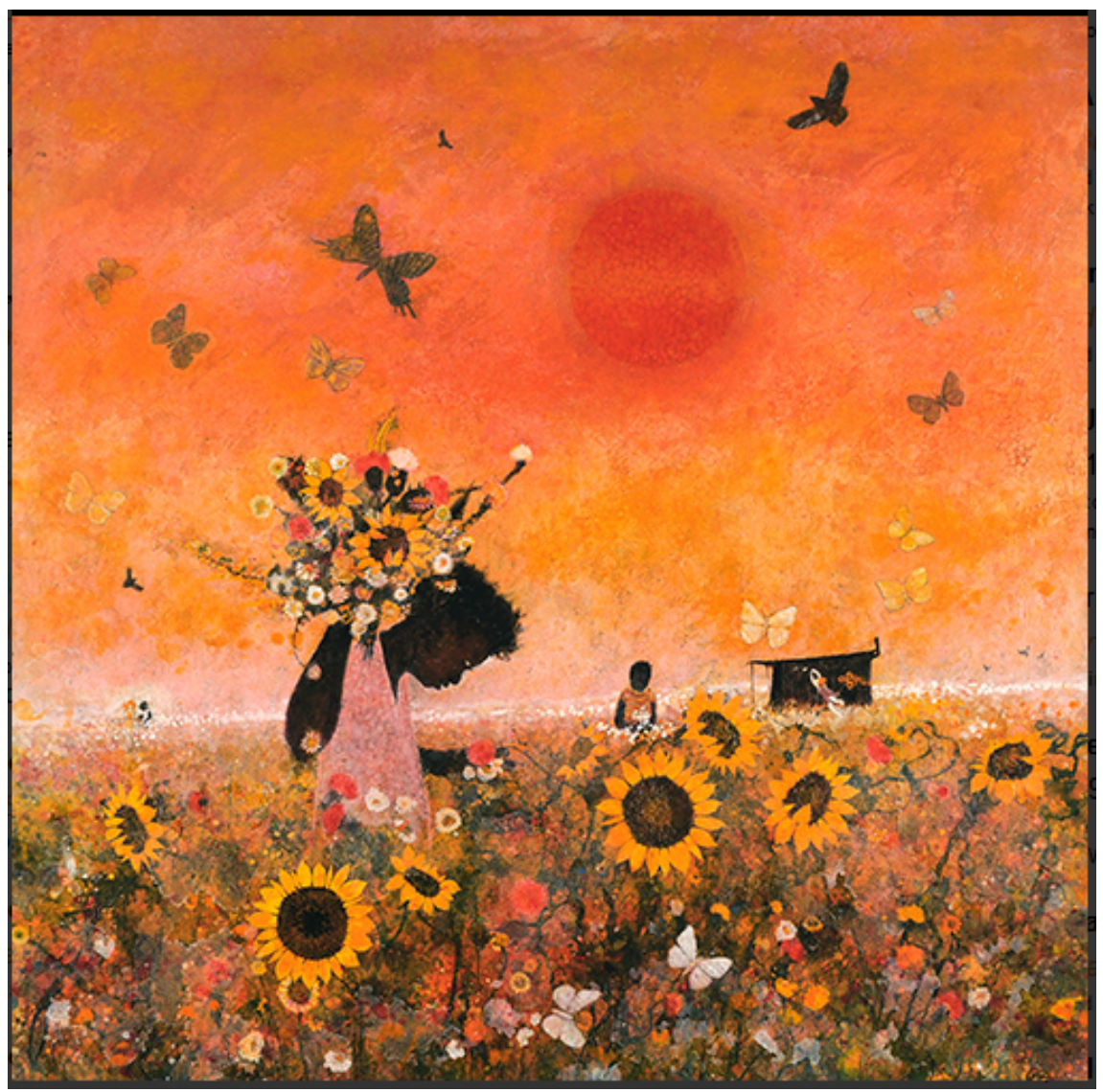

Figure 2. Walter Williams Southern Landscape (1977-1978) Mixed media on board, 48" x 48". David C. Driskell Center at the University of Maryland, College Park. Courtesy of Walter Williams' Estate

Description of evocative key exhibitionary moments

Visitors could watch clips from the Danish documentary Cool Cats (2015) by Janus Køster-Rasmussen, about jazz musicians Dexter Gordon and Ben Webster's experiences in Denmark. Or, they could view the many videos of their performances like Stuff Smith playing his violin with another African American expatriate, pianist Kenny Drew, and two Danish musicians who regularly performed with the expatriates-bassist Niels-Henning $\varnothing$ rsted Pedersen and drummer Alex Riel. A clip from Ken Burns' documentary Jazz about Louis Armstrong arrival in 
Copenhagen in the 1930 s depicted when " 10,000 fans turned out to meet him at the railroad station. He filled the Tivoli concert hall eight evenings in a row" (Burns, 2004).

Marian Anderson singing "Ave Maria" fills the space as she sings the song she sang for prisoners in Horsens Prison in 1935 and visitors could read the local newspaper coverage about her visit or excerpts from the memoir of her Finnish accompanist Kosti Vehanen. The prisoners wrote letters home about the concert, one wrote, "I never heard anything like it, it was an experience we were all grateful for" and these could be part of the exhibit too.

While listening to Alberta Hunter singing for Danish Radio in the 1930s visitors can read her poignant letter written to the United States' Department of State asking to return to Denmark after the Nazi occupation to fulfill her contract to perform. She could not get work in the United States and wanted to be in a place where her "color was not a curse."

Visitors might be surprised to hear classical music performed by Eugene Haynes who fought stereotypes about the kind of music African Americans could play and perform in Denmark. His friendship with Out of Africa author Isak Dinesen a.k.a. Karen Blixen-captured in photographs-could also be displayed. In 2012, the local Amager Museum exhibited items found in Haynes' suitcase including a 1957 Danish magazine article in Billed Bladet, translated to "There's a Negro in Drag $\varnothing r$," that documented Haynes life in the town where he rented a cottage and these items could form part of an exhibit.

Visitors could watch scenes from the Danish film Oh Happy Day (2004) by Hella Joof about an African American choir director from Harlem who teaches a choir in a small Danish village to sing gospel. They could also read a quote from the African American lead actor Malik Yoba stating, "I absolutely loved living and working in Denmark for a few months. It was one of the highlights of my career being able to be immersed in the Danish culture and experiencing how they treat filmmaking."

As I researched Searching for Utopia I constantly searched for photographs of African Americans in Denmark. I would share some of the discovered images including Booker T. Washington in Ringsted in 1910 and his quote, "Perhaps, the happiest country in the world is Denmark." Or, images from the scrapbook Professor Giles Hubert assembled from his year studying in Denmark from 1938 - 1939. There are photographs from the early 1930s of the first two African American students, Wenonah Bond and Floria Pinkney, to attend the still-existing International People's College in Helsing ør. Visitors can see the exquisite black \& white photographs of journalist Roy De Coverley taken of him walking around Copenhagen in the 1950s. They can read quotes from his article, "Race Question Not in Existence in Denmark" written in 1935 for the African American newspaper the Chicago Defender and from his travel narrative "Beauty, Beer and Beechwoods," where he declared Denmark was a "Utopia" and an "Arcadia."

Disturbing images of performers in blackface are juxtaposed against the film Green Pastures (1936) directed by William Keighley and the playwright Marc Connelly based on his 1930 Pulitzer-prize winning play about African Americans recreating scenes from the Old Testament. The play was performed at the Betty Nansen Theatre in Denmark in the 1930s with Swedish and Danish actors in blackface. The Royal Danish Library has a scrapbook of Danish newspaper coverage in their archives.

Visitors will be entranced by a short video, Dancing Prophet, of dancer Doug Crutchfield in Denmark teaching physically disabled children and senior citizens how to dance while reading the 1971 African American magazine Ebony article about Crutchfield titled, "Thanks to Doug Crutchfield Fru Nilsen Can Dance."

A 1963 Down Beat magazine interview, "Sahib Shihab's Expatriate Life," noted: 
Recently, a Danish television producer, Annett Wolf, picked Shihab to portray a guide for a filmed tour of the less-frequented areas of Copenhagen. Trailed by a camera, the baritonist made a fascinating tour of the city, ending up at the Montmartre playing with a trio. The TV vignette, for which Shihab composed and played the soundtrack, won critical applause... (Lind, 1963, p. 38).

Visitors could view this beautiful black \& white vignette.

The aforementioned David Driskell recorded a casual conversation he had with artist Walter Williams discussing what Black art is and what it means to be a Black artist in November 1972 during Driskell's visit to Copenhagen.

African American expatriate Bernie Moore hosted a two-part cinéma vérité show, Anden Mands Land, on Danish television in September and October 1970. Moore talked to African American expatriates about their experiences in Denmark including with racial discrimination.

In 2018, Pulitzer-prize winning poet Gregory Pardlo published his autobiography, Air Traffic: A Memoir of Ambition and Manhood in America, which includes a vignette about his short time in Denmark in the early 1990s. He loved the idea of Denmark and not being another African American making a pilgrimage to Paris, France, which he called a "cliché." He said, "Copenhagen was my calling, and a hipper Promised Land than Paris for black intellectuals escaping the stifling air pollution of American racism" (p. 121). He admitted that "weeks earlier he couldn't have located" Denmark on a map. But, he said he "did my homework." And, he knew that "Copenhagen had attracted black artists, musicians, and writers like Walter Henry Williams, Don Cherry, William H. Johnson, and Nella Larsen" (p. 121). Visitors can read his poem Copenhagen, 1995 that begins,

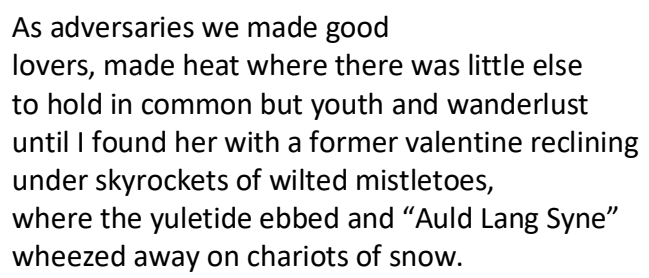

Finally, they can listen to a podcast, about the last of the great jazz musicians, "A portrait of Horace Parlan" on KCRW's Unfictional series from April 8, 2016.

These are just a few of the possible snapshots of items that could be included in my curatorial dream. My archive contains hundreds of items that I am using to assemble a narrative about the experiences of African Americans in Denmark during the $20^{\text {th }}$ century. Not everyone found their utopia in Denmark, but many found great joy living in an environment where they were not considered second-class citizens. Many still missed family, friends, and specific food from the United States but were content to live and die in Denmark. The exit of the exhibition could be a hallway filled with images from the Black Lives Matter movement in Denmark, images of events surrounding the one hundredth anniversary of the transfer of the Danish West Indies to the United States in 1917 (now the US Virgin Islands) and the acknowledgment of Denmark's role in the slave trade along with images of the recently installed Freedom and I Am Queen Mary statues disrupting the utopian narrative for people of African descent born in Denmark or refugees or immigrants not from the United States. The hallway could end with the vibrant shades of pink, orange, and yellow from Williams' landscape paintings and the sounds of jazz filling the air as visitors walk through another field of sunflowers that they could take with them as a souvenir.

Ethelene Whitmire is a professor at the University of Wisconsin - Madison in the Department of Afro-American Studies affiliated with the Department of German, Nordic, and Slavic. She was a 2016-2017 Fulbright Scholar at the University of Copenhagen and is writing a book about African Americans in 20th century Denmark. 


\section{References}

Angarita, M. J. (2016). Conflicted Memory: Military and Cultural Interventions and the Human Rights Era in Peru. Available at http://capsl.cerev.ca/visual-footnotes/

Andrews-Dryer, H. (2014, November 10). 5 Minutes with Samuel Jackson. Or not,. Washington Post Available at https://www.washingtonpost.com/news/reliable-source/wp/2014/11/10/5-minutes-with-samuel-jacksonor-not/?noredirect=on\&utm term=.b59ecca9db5a

Burns, K. (2004). Jazz: A film. Hollywood, Calif.: PBS Home Video; Distributed by Paramount Home Entertainment.

Butler, S. R. (2018). The practice of critical heritage: Curatorial dreaming as methodology. Journal of Canadian Studies, 52(1), 280-305.

Butler, S. R., \& Lehrer, E. (Eds). (2016). Curatorial dreams: Critics imagine exhibitions. Montreal: McGill-Queen's University Press.

Driskell, D. C. (2001). The other side of color: African American art in the collection of Camille O. and William H. Cosby, Jr. San Francisco: Pomegranate. Citation \#31 - "Walter Williams, conversation with author during an artist-in-residency at the Department of Art, Fisk University, Nashville, TN, 1968."

Hanks, E. (2007). A Child of the Universe...Speak Like a Child: Mildred Thompson and Walter Williams. The International Review of African American Art, 21(2), 12-31.

Kossmann, H., Mulder, S. \& den Oudsten, F. (2012). Narrative spaces: On the art of exhibiting. Rotterdam: 010 Publishers.

Lind, J. 1963. Sahib Shihab's Expatriate Life. Down Beat 30 (7), 17, 38.

Smithsonian National Museum of African Art (2014). Nature as Metaphor. Available at http://conversations.africa.si.edu/themes/nature-as-metaphor/

Vecsey, G. V. (1970, January 17). \$90,000-a-Year Rebel. New York Times.

Williams, W., Driskell, D. C., Hanks, E., \& M. Hanks Gallery. (2005). The artwork of Walter Williams. Santa Monica, CA: M. Hanks Gallery.

\footnotetext{
i The museum was criticized for having an exhibition mainly consisting of works from Cosby's collection and receiving a substantial amount of funds from Cosby to mount the exhibition while he was under allegations of sexual assault in 2015. He was later convicted and sentenced in 2018. (see: Bufferstein, A. Smithsonian Conveniently Concealed $\$ 716,000$ Bill Cosby Donation Amid Rape Allegations. Available at https://news.artnet.com/art-world/smithsonian-concealed-bill-cosby$\underline{\text { donation-316275 }}$
} 